\title{
BRIBERY AND INTERNATIONAL COMMERCIAL ARBITRATION - THE ROLE OF MANDATORY RULES AND PUBLIC POLICY
}

\author{
Vladimir Pavić ${ }^{*}$
}

\begin{abstract}
Although designed to resolve private disputes, usually commercial in nature, arbitration may nevertheless encounter during its course allegations of impropriety and criminal behaviour. In the context of international commercial arbitration, the most common of those are allegations of bribery. However, tribunals may adjudicate only matters of private law and, should they establish existence of bribery, may draw only civil law consequences thereof. An additional problem in this respect is determining the body of rules that will be applicable in defining the very notion of bribery, since some aspects of bribery are almost universally prohibited, while the others are banned only in certain jurisdictions. In determining the law applicable to the matters of bribery, tribunals then face choice-of-law dilemmas. Each of the public policy techniques (overriding mandatory provisions, international and/or transnational) has its strengths and weaknesses.
\end{abstract}

\section{INTRODUCTION}

If one were to judge only by the recent proliferation of articles and studies on the appearance of issues of corruption (bribery in particular) before arbitration tribunals, one would be tempted to conclude that international commercial arbitration attracts the crooked and wicked more often than not, and does so at an increasing rate. That, of course, would be a hasty and unwise conclusion. International commercial arbitration cannot be dissociated from commercial reality where some people, even in the best of times, are ready to resort to the worst of means. The service of dispute resolution, just like any other service, is open to everyone who wants it and is able to afford it. Consumers of arbitration services are, therefore, a relatively neutral sample of the overall

* Associate Professor, Faculty of Law, University of Belgrade; Vice-President of the Permanent Arbitration Court attached to the Serbian Chamber of Commerce; pavic@ius.bg.ac.rs. An outline of this paper was presented at a symposium held at Victoria University, Wellington, on 7 November 2012. 
commercial sphere, and are not, in themselves, particularly inclined towards illegal methods of doing business.

Instead, the increase in the number of scholarly and other studies on issues of corruption in arbitration is probably due to a combination of factors. First, it is to be expected that the service providers (arbitration practitioners) start paying attention to the sort of customers they attract and start thinking about the best ways in which (not) to deal with some of them. Corruption is a fact of life (and in some countries a common one), so one has to prepare for the cases that might end up before him or her. Second, the business and legal community has become increasingly sensitive towards corruptive practices. This is not only reflected in the intensified legislative action aimed at combating corruption and other fraudulent acts and practices, but also in the rise of the so-called "anti-corruption industry". ${ }^{1}$ As the business of fighting corruption matures, its proponents become more vocal and its goals and methods better articulated. Finally, one has to admit that certain features of arbitration can potentially make arbitration attractive to the customers that we can all live without. Although the perception of secrecy is a myth, confidentiality of the proceedings is normally sufficient to strip the adjudicative process of the publicity traditionally associated with court proceedings. Thus, if the disputed deal was not of a pristine nature, opting for arbitration might offer additional comfort to the parties. However, as will be shown in this article, arbitration is anything but a safe harbour for such actors.

What are the additional challenges posed by issues of corruption and the like in international commercial arbitration? Some of those challenges appear because corruption is contrary to the public policy and mandatory norms of - depending on the definition of bribery - many or all jurisdictions. Others are the result of an intersection between criminal and private law and the difficulties that sometimes arise when one has to deal with private law consequences before the criminal judge has had his or her say (for example, the issue of the standard of proof, which has been elaborated in detail by many authors). ${ }^{2}$ This article will try to focus predominantly on the

1 The emergence of an "anti-corruption industry" is reflected in the rise of international governmental and non-governmental organisations aimed at fighting corruption, such as the Global Compact and the Group of States against Corruption within the Council of Europe, Transparency International, the Extractive Industries Transparency Initiative endorsed by the World Bank Group, and the United Nations Convention against Corruption Coalition (an advocacy group pressing for stricter adherence to the United Nations Convention against Corruption 2349 UNTS 41 (opened for signature 9 December 2003, entered into force 14 December 2005) [UNCAC].

2 See generally Florian Haugeneder and Christoph Liebscher "Corruption and Investment Arbitration: Substantive Standards and Proof" in Christian Klausegger and others (eds) Austrian Arbitration Yearbook (CH Beck, Stämpfli \& Manz, Vienna, 2009) 539; Phillip Landolt "Arbitrators' Initiatives to Obtain Factual and Legal Evidence" (2012) 28 Arb Intl 173; Michael Hwang and Kevin Lim "Corruption in ArbitrationLaw and Reality" (2012) 8 AIAJ 1; and Jeffrey Waincymer Procedure and Evidence in International Arbitration (Kluwer Law International, The Hague, 2012) at 743-824. 
former set of issues, that is, those stemming from the public policy and mandatory characters of the rules that prohibit corruption.

\section{THE NOTION OF BRIBERY}

The very notion of "bribery" (and "corruption") in international trade seems to provoke an almost unison condemnation. Legal commentators and judges alike have been resolute in labelling it as a vile, repugnant behaviour that tears the very fabric of society and the cross-border exchange of goods and services. ${ }^{3}$ One tribunal noted that bribery is a crime "more odious than theft" and that some jurisdictions rank it next to high treason. ${ }^{4}$ Yet, what is understood to represent "corruption" and "bribery" differs to a significant extent between jurisdictions. This deceptive failure to use consistent labelling across jurisdictions is familiar to European arbitration practitioners who follow American jurisprudence in arbitral matters (and vice versa). In any event, different understandings of what constitutes corruption and bribery in the context of international trade necessitates further examination.

A good starting point is a definition offered by Abdulhay Sayed in perhaps the most voluminous take on the issue of corruption in arbitration, published almost two decades ago: acts of corruption in international trade are "actions of transfer of money or anything of value to foreign public officials, either directly or indirectly, to obtain favorable public decisions in the course of international trade". 5 This definition is in tune with what appears to be a broad consensus - or at least the lowest common denominator - of what the notion of bribery is in international trade. However, to see the entire picture, one has to include other forms of potentially illicit behaviour. ${ }^{6}$

The next step towards discovering what constitutes corruption and bribery in the context of international trade should be a legal analysis of the incrimination of bribery. Bribery amounts to the inducement of persons to act corruptly in the performance of their duties. Normally, those duties are of a public nature, discharged in the public interest. The United Nations Convention against Corruption (UNCAC) ${ }^{7}$ defines two main types of bribery. The first type is "public bribery", which consists of an intentional promise, offer, or a gift given to a domestic or foreign official, directly or

3 See generally Abdulhay Sayed "La question de la corruption dans l'arbitrage commercial international: Inventaire des solutions" (2001) 19 ASA Bulletin 653; Hilmar Raeschke-Kessler and Dorothee Gottwald "Corruption" in Peter Muchlinski, Federico Ortino and Cristoph Schreuer (eds) The Oxford Handbook of International Investment Law (Oxford University Press, New York, 2008) 584 at 609; and Himpurna California Energy Ltd v PT (Persero) Persusahaan Listruik Negara (Final Award) (1999) 25 YBCA 13.

4 World Duty Free Company Ltd v Kenya (Award) ICSID ARB/00/7, 31 August 2006 at [173].

5 Abdulhay Sayed Corruption in International Trade and Commercial Arbitration (Kluwer Law International, The Hague, 2004) at xxiii.

6 Ibid. Sayed has limited his scope of study to public bribery only.

7 UNCAC, above n 1 . 
indirectly, that provides an undue advantage (be it for the official himself or herself, or a third party), so that the official discharges his or her official duties in a certain way or refrains from doing so. ${ }^{8}$ On the side of the recipient, public bribery manifests itself in solicitation or acceptance of the kind of bribe defined above. ${ }^{9}$ The other main type of bribery is labelled as "private": here, the actors mimic the behaviour of the actors of public bribery - except that the recipient of the bribe is incited (or solicits the bribe) not to act in accordance with his or her private sector duties (that is, towards his or her employer or principal). ${ }^{10}$

Generally speaking, public bribery is universally outlawed. The UNCAC has 163 State parties to it, ${ }^{11}$ and they have pledged that they "shall adopt" legislation that outlaws bribery of their own public officials, in both of its forms (offering or giving bribes and accepting them). ${ }^{12}$ In addition, the

8 Article 15(a)

9 Article 15(b).

10 Article 21. See for example Bundesgesetz Gegen den Unlauteren Wettbewerb (Austria), $\$ 10$ (translation: Federal Law Against Unfair Competition); Code pénal (Belgium), art 504bis, §1, [1] and [2]; Criminal Code RSC 1985 c C-46 (Canada), s 121; Criminal Code (Czech Republic), s 128b; Straffeloven (Denmark), s 299 (translation: Criminal Code); Penal Code (Finland), ch 30, s 7; Strafgesetzbuch (Germany), s 299 (translation: Criminal Code); Criminal Law Convention on Corruption (Greece), arts 7 and 8; a Büntető Törvénykönyvről (Hungary), s 253 (translation: Criminal Code); Penal Law (Israel), s 291; Il Codice Civile Italiano (Italy), s 2635 (translation: Italian Civil Code); Loi du 23 mai 2005, Journal Officiel (Luxembourg), A-n 74 at 1176, s 3 (translation: Law of 23 May 2005 on Bribery in the Private Sector); Wetboek van Strafrecht (the Netherlands), art 328ter (translation: Criminal Code), read jointly with Penal Code (the Netherlands), art 51; Secret Commissions Act 1910 (New Zealand), ss 3, 4 and 8; Lovom den almindelige borgerlige Straffelovs Ikrafttræden (Norway), ch 26, s 275 (translation: General Civil Penal Code), and Savings Bank Act (Norway), s 20; Kodeks karny (Poland), art 296a (translation: Criminal Code); DL 28-84 com alterações regime em vigor em matéria de infracções antieconómicas e contra a saúde pública (Portugal), arts 41-B.1 and 41-C.1 (translation: Law number 28/84 of January 20: Changes the system in force in respect of offenses against uneconomic and public health); Trestný Zákon (Slovakia), ss 160 and 161 (translation: Criminal Code); Criminal Code 2007 (Slovenia), arts 245-248; Brottsbalken (Sweden), s 2, ch 20 (translation: Penal Code); Code pénal (Switzerland), art 158; Bribery Act 2010 (UK), ss 1-3.

All the data on national laws and relevant subsections and paragraphs of the named statutes or codes was taken from the information provided by respective national authorities of the States parties to the UNCAC available at the United Nations Office on Drugs and Crime portal "Legal Library" (2011) TRACK <www.track.unodc.org>.

11 For the status of the UNCAC see United Nations Office on Drugs and Crime "United Nations Convention against Corruption" (2012) <www.unodc.org>.

12 UNCAC, above n 1, at art 15 . The list of States that effectively outlawed public bribery pursuant to the obligations under art 15 of the UNCAC comprises of the following:

Europe and Asia region: Albania, Angola, Armenia, Austria, Azerbaijan, Bahrain, Bangladesh, Belarus, Belgium, Bhutan, Bosnia and Herzegovina, Brunei Darussalam, Bulgaria, Cambodia, China, Croatia, Cyprus, Czech Republic, Denmark, Estonia, Finland, France, Germany, Gibraltar, Greece, Guernsey, Hong Kong, Hungary, Iceland, India, Indonesia, Iraq, Ireland, Israel, Italy, Japan, Jersey, Jordan, Kazakhstan, Korea, Kuwait, Kyrgyzstan, Lao, Lebanon, Lichtenstein, Lithuania, Luxembourg, Malaysia, Maldives, 
State parties have made further pledges when it comes to bribery of foreign public officials. However, the pledges in this matter have not been of uniform firmness: while all State parties promised that they will outlaw promising or giving bribes to foreign officials, they have only undertaken to "consider" outlawing solicitation or acceptance of bribes by foreign public officials. ${ }^{13}$

Malta, Moldova, Mongolia, Montenegro, Morocco, Myanmar, Nepal, Netherlands, Norway, Pakistan, Palau, Philippines, Poland, Portugal, Qatar, Romania, Saudi Arabia, Serbia, Singapore, Slovakia, Slovenia, Spain, Sri Lanka, Sweden, Switzerland, Syrian Arab Republic, Tajikistan, Former Yugoslav Republic of Macedonia, Timor Leste, Tunisia, Turkey, Ukraine, United Arab Emirates, United Kingdom, Uzbekistan, Vietnam and Yemen.

North, Central and South America and the Caribbean: Antigua and Barbuda, Argentina, Bahamas, Barbados, Bermuda, Belize, Bolivia, British Virgin Islands, Canada, Cayman Islands, Chile, Colombia, Costa Rica, Cuba, Dominica, Dominican Republic, Ecuador, El Salvador, Fiji, Guatemala, Guyana, Haiti, Honduras, Jamaica, Mexico, Nicaragua, Panama, Paraguay, Peru, Trinidad and Tobago, Uruguay, United States of America and Venezuela.

Africa, Australia and New Zealand: Afghanistan, Algeria, Australia, Benin, Botswana, Burkina Faso, Burundi, Cameroon, Cape Verde, Central African Republic, Comoros, Congo-Brazzaville, Cook Islands, Cote d'Ivoire, Democratic Republic of the Congo, Djibouti, Egypt, Ethiopia, Gabon, Guinea, GuineaBissau, Kenya, Lesotho, Liberia, Libyan Arab Jamahiriya, Madagascar, Malawi, Mali, Mauritius, Mozambique, Namibia, New Zealand, Niger, Nigeria, Papua New Guinea, Rwanda, Sao Tome and Principe, Senegal, Sierra Leone, South Africa, Sudan, Swaziland, Tanzania, Togo, Uganda, Vanuatu, Zambia and Zimbabwe.

All the data on States incriminating public bribery under art 15 of the UNCAC has been compiled from the information available at the United Nations Office on Drugs and Crime portal "Legal Library", above n 10.

13 UNCAC, above n 1, at art 16(2). In this respect only a smaller number of State parties to the UNCAC implemented the solicitation/acceptance of bribes provisions. See for instance: Strafgesetzbuch (Austria), § 307 (translation: Austrian Penal Code); Criminal Code Act 1995 (Australia, Cth), s 70.2; Code pénal (Belgium), above n 10, at art 250; Corruption of Foreign Public Officials Act SC 1998 c 34 (Canada), s 3; Straffeloven (Denmark), above n 10, at s 122; Code penal (France), ss 435-1, 435-2 and 435-3; Strafgesetzbuch (Germany), above n 10, at s 334, and Gesetz zu dem Übereinkommen vom 17 Dezember 1997 über die Bekämpfung der Bestechung ausländischer Amtsträger im internationalen Geschäftsverkehr (Germany), ss 1-4 (translation: Law to the Convention of 17 December 1997 on Combating Bribery of Foreign Public Officials in International Business Transactions); Law 2803/2000 on the protection of the financial interests of European Communities (Greece), arts 2 and 3, Law 2802/2000 ratifying the EU Convention against Corruption of officials (Greece), art 4, and Law 2656/2000 (Greece), arts 2 and 3; a Büntető Törvénykönyvröl (Hungary), above n 10, at ss 258B, 258C and 258D; Prevention of Corruption Act 1916 (Ireland), art 1 (as amended by the Prevention of Corruption Act 2001, art 2), and the Criminal Justice (Theft and Fraud Offences) Act 2001 (Ireland), art 44; Unfair Competition Prevention Law (Japan), arts 11(1), 11(2), 14 and 15; Código Penal Federal (Mexico), art 222bis; Wetboek van Strafrecht (the Netherlands), above n 10, at arts 178a and 364a; Crimes Act 1961 (New Zealand), s 105(c); Criminal Code of the Kingdom of Norway (Norway), ch 12, s 127; Kodeks karny (Poland), above n 10, at arts 228 and 229; Lei 34/87 com alterações Crimes de Responsabilidade dos Titulares de Cargos Políticos (Portugal), arts 16 and 17 (translation: Law 34/87 of 16 July regulating the crimes of responsibility of political appointees); Trestný Zákon (Slovakia), above n 10, at ss 160b and 160c; Criminal Code 2007 (Slovenia), above n 10, at art 267; Código Penal (Spain), art 445; Brottsbalken (Sweden), above n 10, at s 2, ch 20; Code pénal (Switzerland), above n 10, at art 322 septies, [2]; Bribery Act 2010 (UK), above n 10, at s 6, and Anti- 
This difference in attitude is worth noting, although it can be at least partly attributed to a preference for more conservative facets of territorial bases of jurisdiction in criminal matters (that is, subjective and objective territoriality).

Public and private bribery are not the only forms of corruption in international trade that are outlawed. There are two further arrangements of importance. The first one, known as "trading in influence", takes place where someone trades the abuse of his or her real or supposed influence over public bodies or officials. This not only includes offering or giving bribes in exchange for such real or supposed influence, but also the solicitation or acceptance of bribes in exchange for a promise to influence the decision-making of State bodies and officials so that "undue advantage" is obtained. ${ }^{14}$ The prohibition of this practice is not uniform, and this is reflected in the text of the UNCAC, where the signatories promised only to "consider" incriminating such behaviour. ${ }^{15}$ The second arrangement relates to so-called "facilitation payments", used to "grease" and expedite an action that a government or its officials would be obliged to perform in any event. Whilst some international documents and State laws expressly prohibit such payments, others permit them under certain circumstances. ${ }^{16}$

terrorism, Crime and Security Act 2001 (UK), s 108; Racketeer Influenced and Corrupt Organizations (United States) 18 USC $\$ 1962$ and $§ 1963$.

All the data on national laws and relevant subsections and paragraphs of the named statutes or codes was taken from the information provided by respective national authorities of the States parties to the UNCAC available at the United Nations Office on Drugs and Crime portal "Legal Library", above n 10.

14 UNCAC, above $\mathrm{n} 1$, at art 18(a).

15 Article 18

16 It is interesting to note that within the OECD framework, a majority of the States have decided to incriminate "facilitating payments" (the list includes Argentina, Belgium, Brazil, Bulgaria, Chile, Czech Republic, Denmark, Estonia, Finland, France, Germany, Hungary, Iceland, Ireland, Israel, Italy, Japan, Luxembourg, Mexico, the Netherlands, Norway, Poland, Portugal, Russia, Slovenia, Sweden, Turkey, and the United Kingdom); while a smaller number of States has decided on excluding facilitating payments from the scope of their definitions of outlawed, bribery-like behaviour. This group of States includes Australia, Austria, Canada, Greece, South Korea, New Zealand, Slovak Republic, South Africa, Spain, Switzerland and the United States. See the research and post by Andy Spalding, Assistant Professor at the University of Richmond School of Law, at Andy Spalding "Facilitating Payments (De)mystified (Part II)" (13 June 2012) The FCPA Blog <www.fcpablog.com/blog>. Some authorities, such as the Serious Fraud Office in the United Kingdom, wanted to make sure that the official stance towards "facilitation payments" amounts to zero tolerance, as noted by Chief Investigator Keith McCarty. A copy of the Serious Fraud Office's report is available at Bryan Cave "Enforcement of the UK Bribery Act - Facilitation Payments" (10 October 2011) <www.bryancave.com/files/Publication>. However, even for the States that have accepted "facilitation payments" as non-criminalised behaviour (such as Australia), the scrutiny of the United Nations and the general perception of the global community might shift their stance on the point. As noted in the report of the UNCAC Implementation Review Group, which reviewed Australia's compliance with the UNCAC, from late June 2012, "Australia should consider continuing to review its policies and approach on facilitation payments in order to effectively combat the phenomenon": Review of implementation of the 
As this brief outline shows, a working definition of what constitutes "bribery" in international trade is difficult to delineate. While there is a consensus on the very core policy (when it comes to public bribery), the support for outlawing other arrangements (private bribery, peddling of influence, facilitation payments) is not nearly as solid. For the purposes of this article, all four modalities will be taken into consideration, as it is the differences between them and the different attitudes toward them that present the most acute challenges for international commercial arbitration.

\section{TYPICAL SCENARIOS - THE APPEARANCE OF BRIBERY}

There are a myriad of ways in which criminal elements might appear within a dispute that is to be resolved by arbitration, or that has already been resolved by it. The sheer number of possible scenarios falls outside of the scope of this article, but some will be mentioned. The least likely is the criminal conduct of the arbitrators themselves: for example, if they become involved in a brawl, demand and accept bribes, or otherwise engage in criminal activities in the course of the arbitration. Somewhat less rare are the fraudulent and criminal acts of other actors during the course of the proceedings: false testimony, forged documents, unlawful surveillance of the parties and the arbitrators, and so on. Somewhat more often, illegality is not intrinsic to the proceedings, but has instead taken place at some prior time and is invoked during the proceedings by one of the parties.

This article will examine the consequences of a variant of the latter scenario listed above - the one in which during the course of proceedings, it is alleged (or becomes apparent) that at some prior time one of the parties (or both) has resorted to bribery. The most common scenario involves contracts where the agent (intermediary) undertakes to assist its principal in obtaining a certain contract or permission. ${ }^{17}$ The contract is obtained, but the principal refuses to pay the agents a "reward" or "commission" and the matter is brought before arbitration. Defaulting respondents then often go on to argue that the contract of agency was a vehicle for bribery and that to pay remuneration to the agent would amount to reimbursement for the bribes paid to the officials who have awarded the contract. ${ }^{18}$

United Nations Convention against Corruption: Executive Summary CAC/COSP/IRG/I/2/1 (2012) at 3. Accordingly, it comes as no surprise that this issue is currently under review by the Australian authorities see Australian Government Attorney-General's Department "National Anti-Corruption Plan" (16 January 2012) <www.ag.gov.au/anticorruptionplan>.

17 See for example Broker v Contractor (Final Award) (1988) 19 YBCA 105; Consultant (Liechtenstein) $v$ Contractor (Germany) (Final Award) (1994) 24a YBCA 71; Company S v Company F (Final Award) (1998) 4 J Droit Intl 1076; State-Owned Corporation X v Corporation Y (Final Award) (2003) 33 YBCA 24; Consultant v German Company (2005) 31 YBCA 685; Thales $v Y \& Z$ Swiss Federal Tribunal 4A.596/2008, 6 October 2009.

18 According to one estimation, "systemic corruption can add $20-25 \%$ to the costs of government procurement, and frequently results in inferior quality goods and services and unnecessary purchases": Transparency International "Public Contracting" <http://archive.transparency.org>. Highlights to the 2005 
When bribery issues - such as those laid out in the "agency/intermediary" scenario above - arise before an arbitration tribunal, they in turn trigger a number of legal questions, including:

- $\quad$ whether the tribunal is allowed to adjudicate (hear) the matters tainted by bribery;

- whether the arbitrators can investigate sua sponte and whether they are obliged to report their suspicions or findings to the authorities;

- what the appropriate standard of proof is;

- what the law applicable to private law consequences of bribery is, and how a particular rule will affect the outcome of the dispute; and

- whether and how the issue of bribery can potentially be revisited before the State courts in proceedings for the setting aside, or recognition and enforcement, of the arbitral award.

As has been mentioned, bribery and corruption cause particularly strong opprobrium since they are perceived to be contrary to the core values of most legal systems. In other words, prohibition of bribery is a matter of public policy and the mandatory rules of nation States. This article will limit its overview of bribery issues in arbitration to those that might cause particular problems precisely because of the overlapping layers of the norms comprising overriding mandatory provisions, national and international public policy. Thus, it will concentrate on the potential investigative and reporting role of the arbitral tribunal, the choice of law and rules applicable to the issue of bribery, the outcome of such choice and the standard of review by the courts.

The other two issues (jurisdiction and the standard of proof), which will be left out of the scope of this work, have, in the course of the past few decades, suffered completely different fates. Nowadays it is considered a settled issue that arbitrators have jurisdiction to hear a dispute even if it involves bribery allegations. Whether they will deem the claim admissible, though, is another matter. In any event, the principle of separability will on most occasions be more than sufficient to shield the jurisdiction of the tribunal from the "it's about bribery!" torpedo allegations. ${ }^{19}$ When it comes to the issue of standard of proof, however, no clear consensus emerges: one can find a plethora of reasoned positions why those alleging bribery have to meet a "high" standard, one of "balance of probabilities", or why, once the allegation is made, the burden should be reversed and shifted to the alleged perpetrator to disprove. ${ }^{20}$ This divergence of potentially appropriate standards

Transparency International Report delineate that pursuant to surveys conducted and reported, corruption is repeatedly greater in construction than in any other sector of the economy: Transparency International "Global Corruption Report 2005" (press release, 16 March 2005) at Highlights.

19 The principle of separability entails that the validity of the main contract and the arbitration clause will be examined separately. Thus, a finding that the main contract is invalid will not automatically result in finding that the arbitration clause is invalid as well.

20 For a comprehensive overview of the matter, see Stephan Wilske and Todd J Fox "Corruption in International Arbitration and Problems with Standard of Proof: Baseless Allegations or Prima Facie Evidence?" in Stefan Michael Kröll and others (eds) International Arbitration and International Commercial Law: Synergy, Convergence and Evolution (Kluwer Law International, The Hague, 2011) 489. 
sometimes allows the tribunals to make up their minds and justify their decisions by applying a standard of proof that validates their findings.

\section{ARBITRATORS AS "GLOBOCOPS" - SUA SPONTE INVESTIGATION AND REPORTING TO THE AUTHORITIES?}

A typical scenario of introducing allegations of bribery in international commercial arbitration usually involves allegations of bribery being invoked by one of the parties. However, this is not necessarily always so, and the arbitrators might be presented with a somewhat different scenario, one in which the parties carefully "dance around" the issue of bribery. ${ }^{21}$ Defaulting respondents could, for instance, claim that they have obtained a contract solely through their own efforts (that is, that the claimant did nothing to help). As a first line of defence this approach might serve a valid purpose, especially as it avoids the risk of presenting one's own business as "ready to use bribery for convenience, but not ready to foot its bill". Should arbitrators observe such an exchange of arguments, or similarly, equally suspicious exchanges, without digging deeper and asking the parties to provide more facts about the true nature of the underlying contract? In other words, are arbitrators able to investigate possible bribery sua sponte, or are they limited to the evidence the parties present without any further investigation?

The answer to this is influenced by several considerations.

On the one hand, arbitration performs a judicial function. ${ }^{22}$ The goal of the arbitral process is to reach a decision, and the State provides such a decision with standing equal to that of a final judgment of a State court. In that respect, arbitration appears as a sort of private supplement to the judiciary, ${ }^{23}$ and one may reasonably expect that, in return for its decisions being on par with those of State courts, the State and the private parties can rightfully expect that an arbitration approaches matters of public policy and special mandatory norms (that is, bribery) with the same level of

21 The least likely scenario - the one in which both parties admit that bribery was contemplated or has taken place - seldom occurs. But see World Duty Free Company Ltd v Kenya, above n 4; and Argentine Engineer v British Company (Final Award) (1963) 21 YBCA 47.

22 Antoine Pillet Traité pratique de droit international privé (Tenin, Paris, 1924) at 537 (translation: Practical Treatise on Private International Law); Henri Motulsky Écrits: Études et notes sur l'arbitrage (Dalloz, Paris, 1974) at 46 (translation: Writings: Studies and notes on arbitration); FA Mann "Lex Facit Arbitrum" (1986) 2 Arb Intl 241; M Mustill "Transnational Arbitration in English Law" (1984) 37 CLP 133 at 133 142; Philippe Fouchard and others On International Commercial Arbitration (2nd ed, Kluwer Law International, The Hague, 1999) at 10.

23 But not a part of it. When the judiciary contends otherwise - like in the decision of the Croatian Constitutional Court U-III-669/2003, NN 157/04, 27 October 2004 - it is usually met with stark opposition by commentators: see Sinisa Triva "Arbitration and Public Policy: Constitutional Complaint as Means for Setting Aside Arbitral Award" (2000) 7 Croat Arb Yrbk 115; MA Giunio "Ugovor o arbitraži u praksi Ustavnog suda RH" (2005) 2 Pravo u gospodarstvu 56 at 59-67; and D Babić "Ustavna tužba protiv odluke arbitražnog suda o nenadležnosti" (2005) 7 Pravo i porezi 22 at 23-24. 
attentiveness as would be the case with the State judiciary. On the other hand, arbitration is a creature of contract. The will of the parties is indispensible - arbitrators are supposed to serve this will and not impose their own opinions contrary to the parties' determination. ${ }^{24}$

Further, the imperative to protect "public policy" (or apply the mandatory rules of a particular jurisdiction) arises only if the tribunal finds that public policy (national, international, transnational) against the suspected behaviour exists, and that such rules are - because of their international or transnational character, or because of their will to be applied (Anwendungswille), or because of the location of the arbitral seat - supposed to be applied. In other words, the duty to act on suspicion would potentially arise only if the suspected bribery is prohibited by the applicable rules.

Finally, and perhaps most importantly, a tribunal could act upon the imperative to investigate a suspected and prohibited bribery only if such sua sponte inquiry would neither fall outside the general prerogatives of the tribunal, nor endanger the basic pillars of fair proceedings. It seems that such action could hardly qualify as "exceeding its mandate" under art $\mathrm{V}(1) \mathrm{c}$ of the New York Convention ${ }^{25}$ or art 34(2)(a)(iii) of the Model Law. ${ }^{26}$ On the contrary, failure to act sua sponte may produce a decision that inadvertently endorses bribery and opens the resulting award to annulment or non-recognition. ${ }^{27}$

Therefore, arbitrators can and should investigate suspected or manifest illegality sua sponte, whenever the suspected or manifest illegality is relevant for the final decision on claims brought

24 For more on so-called "contractualist" views of arbitration see Frédéric-Édouard Klein Considérations sur l'arbitrage en droit international privé: précédées d'une étude de législation, de doctrine et de jurisprudence comparées en la matière (Helbing \& Lichtenhahn, Basel, 1955) (translation: Considerations on Arbitration in Private International Law: Preceded on a study of Legislation, Doctrine and Jurisprudence on the Matter); Morris Stone "A Paradox in the Theory of Commercial Arbitration" (1966) 21 Arb J 156 at 182; Julian DM Lew, Loukas A Mistelis and Stefan Kröll Comparative International Commercial Arbitration (Kluwer Law International, The Hague, 2003) at 78.

25 Convention on the Recognition and Enforcement of Foreign Arbitral Awards 330 UNTS 3 (opened for signature 10 June 1958, entered into force 7 June 1959) [New York Convention].

26 Model Law on International Commercial Arbitration of the United Nations Commission on International Trade Law GA Res 40/72, A/Res/40/72 (1985) [Model Law].

27 Hwang and Lim, above n 2, at 10; RH Kreindler "Aspects of Illegality in the Formation and Performance of Contracts" (2006) 3 TDM 209 at 253. 
before them. ${ }^{28}$ When they do so, the parties are also able to comment and respond to suspicions of illegality. ${ }^{29}$

The second question is whether the arbitrators should, once they become sufficiently persuaded by the facts presented or inferred from the record, report their suspicions to the authorities. If the bribery is of the sort that is universally proscribed, should it, as a rule, be reported in order to help combat what is viewed as a menace of global proportions? The chances of bribery being reported might depend on two factors. The first is the consideration of confidentiality of arbitral proceedings. The second is the scope and stringency of the reporting duties imposed by relevant jurisdictions.

Confidentiality is often cited as one of the most important advantages of international commercial arbitration, although a closer examination reveals that its reach is somewhat limited. Parties normally expect their arbitral affairs not to reach the general public - national laws generally treat such an attitude benevolently - and arbitrators are happy to collect an extra premium for the confidentiality of their services. The obligation of confidentiality is sometimes express, ${ }^{30}$ more often implied, ${ }^{31}$ and if applicable to the parties it is generally understood to extend to the tribunal

28 RH Kreindler "Is the Arbitrator Obligated to Denounce Money Laundering, Corruption of Officials, etc.? The Arbitrator as Accomplice - Sham Proceedings and the Trap of the Consent Award" in Theodore $\mathrm{H}$ Moran Combating Corrupt Payments in Foreign Investment Concessions: Closing the Loopholes, Extending the Tools (Center for Global Development, Washington DC, 2008) 26.

29 BM Cremades and DJ Cairns "Transnational public policy in international arbitral decision-making" in Kristine Karsten and Andrew Berkeley (eds) Arbitration: Money Laundering, Corruption and Fraud (ICC Publishing, Paris, 2003) 65 at 83.

30 Gary B Born International Arbitration: Cases and Materials (Kluwer Law International, The Hague, 2011) at $791-792$.

31 See in that sense Oxford Shipping Co Ltd v Nippon Yusen Kaisha [1984] 3 All ER 835 (QB) at 842:

The concept of private arbitration derives simply from the fact that the parties have agreed to submit to arbitration particular disputes arising between them and only between them. It is implicit in this that strangers shall be excluded from the hearing and conduct of the arbitration and that neither the tribunal nor any of the parties can insist that the dispute shall be heard or determined concurrently with or even in consonance with another dispute, however convenient that course may be to the party seeking it and however closely associated [with each other] the disputes in question may be.

Dolling-Baker v Merrett [1990] 1 WLR 1205 (CA) at 1213:

\begin{abstract}
As between parties to an arbitration ... their very nature is such that there must ... be some implied obligation on both parties not to disclose or use for any other purpose any documents prepared for and used in the arbitration, or disclosed or produced in the course of the arbitration, or transcripts or notes of the evidence in the arbitration or the award, and indeed not to disclose in any other way what evidence had been given by any witness in the arbitration, save with the consent of the other party, or pursuant to an order or leave of the court.
\end{abstract}

In Esso Australia Resources Ltd v Plowman [1995] 183 CLR 10 at 48, the Australian High Court concluded that the exclusion of the public from arbitration hearings would be rendered meaningless if the parties to the 
too. ${ }^{32}$ The intensity of protection varies - generally, it is stronger when it comes to proper arbitral proceedings, but views differ greatly on what it is that is actually protected. Some hold that documents already existing independently of arbitration - even if later presented before it - are not confidential, while those created during the course of arbitration and solely for the purpose of arbitration (records, rulings, awards, testimonials) are confidential. ${ }^{33}$

In any event, the obligation of confidentiality exists in order to protect private, and not public, interests. By contrast, the obligation to report crime is established in order to protect public interest, and as such will trump obligations of confidentiality whenever the members of the tribunal are subject to such a duty. Where there is no legislative duty of confidentiality, the only consideration is how strong and compelling the rules are establishing the duty to report. Where a statutory obligation of confidentiality exists, the legislators have usually carved out a pretty flexible public interest exception within the law. ${ }^{34}$ In turn, this again means that the existence of a duty to report will depend on the strength of the coercion to do so.

It is necessary to stress that legal systems usually impose a sanctionless duty (sometimes referred to as "a duty and a right") to report a crime. ${ }^{35}$ However, if the crime is of a certain magnitude (usually those prosecuted ex offo, and not proprio motu), failure to report becomes a crime in itself, unless one enjoys a statutory exception. ${ }^{36}$ In addition, public officials and those entrusted with performing public competencies, or those exercising particular responsibilities in

proceedings would be allowed to make the content of the hearings public through television, press or otherwise.

32 Michael Hwang and Katie Chung "Protecting Confidentiality and its Exceptions - The Way Forward?" in ICC Confidentiality in Arbitration: Commentaries on Rules, Statutes, Case Law and Practice (ICC Publishing, Paris, 2009) 40.

33 Dolling-Baker v Merrett, above n 31; Hassneh Insurance Co of Israel v Steuart J Mew [1993] 2 Lloyd's Rep $243(\mathrm{QB})$.

34 See for example in Australia (International Arbitration Act 1974 (Cth), s 23G(1), taking into account amendments up to 2011); New Zealand (Arbitration Act 1996, s 14E(2), reprinted as at 1 January 2011); Scotland (Scottish Arbitration Rules, r 26(1), yet to be implemented). See also generally Ileana M Smeureanu Confidentiality in International Commercial Arbitration (Kluwer Law International, The Hague, 2011) at 16-17 and 20-22.

35 See for example the Criminal Procedure Code of the Republic of Serbia, art 280(1).

36 For example, the Criminal Code of the Republic of Serbia, art 331(1) provides that one is obliged, under threat of fine or imprisonment, to report the preparation of crimes for which a prison sentence of more than five years might be handed down. Even if a law provides for a sanction in the case of failure to report a crime - such as Crimes and Criminal Procedure 18 USC, pt 1, ch $1, \S 4$, which incriminates "misprision of felony" and states that anyone who has a knowledge of crime and fails to report that crime may be fined, imprisoned for up to three years or both - these provisions are rarely applied. For a detailed analysis of this problem, see Sandra Guerra Tompson "The White-Collar Police Force: 'Duty to Report' Statutes in Criminal Theory" (2002) 11 Wm \& Mary Bill Rts J 3. 
juridical persons, are sometimes put under a stricter obligation to report crimes. ${ }^{37}$ Therefore, even if one puts aside the question of "which law applies?" one has to decide whether the arbitrators, although deriving their jurisdiction from the agreement of the parties, also perform their judicial function by virtue of the generosity of the legislator. It is the legislator who has entrusted them with the performance of such competencies, otherwise reserved for State judiciaries. If they are viewed as performing publicly entrusted competencies, arbitrators might have to observe a potentially stricter standard of reporting. ${ }^{38}$

Therefore, arbitrators are potentially subject to two types of duties to report bribery. One is moral and legal, but sanctionless (and proclaimed as such in law); the other is legal and backed by criminal sanctions. Although it is quite possible that obligations of the former kind might occasionally be observed, one should be forgiven for predicting that the arbitrators would in all likelihood pay more attention to obligations of the latter type, in order to avoid criminal punishment. If the threat of sanctions is their only motive, which norms (that is, norms of which jurisdictions) should they observe? It is difficult to provide a simple answer to such a question. The scope of application of criminal law rules is predominantly territorial. Nevertheless, many criminal codes provide protective, personal and universal principles in order to potentially expand the umbrella of their criminal legislation. This means that a failure to report a crime of bribery in accordance with a duty will most likely represent a crime of its own in the country where the bribe was given or accepted, and (given that some laws prohibit the bribing of foreign officials) in the country where the bribe-giver was based. ${ }^{39}$ If the country where the crime was committed is, at the same time, a

37 Criminal Procedure Code of the Republic of Serbia, above n 35, at art 253(2); Criminal Code of the Republic of Serbia, ibid, at art 332(2); Criminal Procedure Code of the French Republic, art 40.

38 Dragor Hiber and Vladimir Pavić "Arbitration and Crime" (2008) 25 J Int Arb 461 at 466 et seq; Hwang and Lim, above n 2, at 14-24.

39 Cooperation in terms of reporting bribes is also enshrined within the UNCAC, above $\mathrm{n} 1$, in the form of a recommendation for the State parties. Namely, art 39(2) provides that:

Each State Party shall consider encouraging its nationals and other persons with a habitual residence in its territory to report to the national investigating and prosecuting authorities the commission of an offence established in accordance with this Convention.

As noted within the Technical Guide to the United Nations Convention Against Corruption United Nations Office on Drugs and Crime (United Nations, New York, 2009) at 123-124, many corruption cases are complex and covert, and would not come to the attention of the relevant authorities - or their investigation would be impaired - without the cooperation of private sector entities, especially financial institutions, as well as private citizens. This is particularly important, as early notification by relevant private sector bodies or early cooperation with investigative agencies may be crucial to the identification and safeguarding of potential evidence and the initiation of inquiries pertaining to bribery cases. The Technical Guide underlines that legal persons or senior management and staff who either report to relevant law enforcement agencies, or cooperate with requests for information, should, where they have acted in good faith and on reasonable grounds, have the assurance of confidentiality and, where the allegations do not lead to an investigation, 
country of the seat of the tribunal, a country of the arbitrator's domicile, or a country where the arbitrator expects to travel or do business, one might expect his or her compliance with the reporting rule to be more likely than in a case where the crime took place in a remote jurisdiction. However, commentators note that it is extremely difficult to identify a case where arbitrators have acted on their duty to report. There are several possible explanations for this. First, arbitrators are normally content to apply civil law sanctions to proven bribery, and their civil law disposition makes them reluctant to assume the role of "globocops" (or "globosnitches"). Second, in the international context, parties often choose a neutral country to be the seat of arbitration. In such case, arbitrators are less likely to feel the urge to check the content of the reporting obligations in relevant jurisdictions and observe them. Finally, in a portion of the cases where bribery was alleged or apparent, criminal complaints were already lodged prior to or during the arbitral proceedings by the party that had claimed the existence of bribery. ${ }^{40}$

\section{THE RULES GOVERNING THE EXISTENCE AND CIVIL LAW CONSEQUENCES OF BRIBERY}

Applying criminal law provisions is often tough, especially when it comes to sentencing. In one respect, however, decision-making in a criminal law case is much easier than in a civil law dispute. When it comes to disputes involving a foreign (international) element, a civil judge typically engages in a conflict-of-law analysis. A criminal judge has no such problems. He can apply only one law - that of the country in whose name he is passing the judgment. ${ }^{41}$

A national judge sitting on a civil law case has to follow the choice of legal doctrine as laid out in the law of his land: it is usually codified in national laws, but can also be contained in precedents. In cross-border matters, legislators normally allow the parties to choose the applicable law, even if the chosen law has no connection with the underlying relationship. This freedom is, however, constrained by two instruments: that of public policy and that of mandatory norms.

When determining the proper law applicable to the contract, the public policy of the forum serves as a safety valve, preventing the application of any rules when the effect of their application would run contrary to the fundamental legal principles of the domestic legal order. The exact content of public policy (ordre public) in this context is usually left unclear. This elasticity and ambiguity serves a useful purpose, as long as it is scrupulously used.

The other possible check on parties' choice of law or on otherwise applicable choice-of-law rules are mandatory norms; mandatory in the true international sense (lois d'application immediate,

should be able to further enjoy protection from civil suits and claims for damages from those involved in the allegations.

40 Or some other crime: see for example AJU $v$ AJT [2011] SGCA 41, [2011] 4 SLR 739.

41 Leaving aside criminal judges operating at an international level. 
Eingriffsnormen). ${ }^{42}$ Applying mandatory norms, or taking them into consideration, is independent of the conflict analysis. In the context of private international law, those norms are usually derived from the laws that lay down the foundations of an economic system. However, criminal law norms can also be viewed as mandatory rules par excellence, ${ }^{43}$ albeit of a nature that allows a foreign judge only to take them into consideration, and not to apply them directly.

While a conflict analysis by a State judge is relatively straightforward, those arbitrating a dispute of international character face a real smorgasbord of choice. ${ }^{44}$ Unconstrained by domestic conflict rules, they are usually instructed to apply the law chosen by the parties or, failing such choice, any rules they find appropriate (that is, most closely connected to the dispute). No traditional conflict methodology is normally required.

This free pass has not resulted in decision-making by fiat. On the contrary, arbitration practice and jurisprudence have been careful to stress that the arbitrators have to observe public policy rules and mandatory norms and draw civil law consequences for violation of said norms. ${ }^{45}$ However, the nature of the arbitrators' mandate and their role as decision-makers who act outside of any judiciary entails a further dilemma: which public policy and which mandatory rules should they observe? In

42 See for example European Parliament and European Council Regulation 593/2008 on the law applicable to contractual obligations [2008] OJ L177/6, art 9(3) [Rome I]; Jonathan Harris "Mandatory Rules and Public Policy under the Rome I Regulation" in Franco Ferrari and Stefan Leible (eds) Rome I Regulation: The Law Applicable to Contractual Obligations in Europe (Sellier, Munich, 2009) 269 at 310 et seq; James Fawcett, Janeen Carruthers and Peter North Cheshire, North \& Fawcett: Private International Law (14th ed, Oxford University Press, Oxford, 2008) at 738 et seq; Swiss Federal Code on Private International Law, art 19; Wolfgang Peter Arbitration and Renegotiation of International Investment Agreements (2nd ed, Kluwer Law International, The Hague, 1995) at 139; Inter-American Convention on the Law Applicable to International Contracts 33 ILM 732 (signed 17 March 1994, entered into force 15 December 1996), art 11; Hague Convention on the Law Applicable to Agency 16 ILM 775 (signed 14 March 1978, entered into force 1 May 1992), art 16.

43 Alexis Mourre "Arbitration and Criminal Law: Reflections on the Duties of the Arbitrator" (2006) 22 Arb Intl 95 at 99; Hiber and Pavić, above n 38, at 469.

44 See for example Swiss Federal Code on Private International Law, above n 42, at art 187; Belgian Judicial Code, art 1700; Arbitration Act 1996 (UK), s 46; International Criminal Court Rules of Arbitration, art 21 [ICC Rules of Arbitration]; American Arbitration Association Arbitration Rules, art 28 [AAA Arbitration Rules]; German Institute of Arbitration Rules, art 23 [DIS Rules]; United Nations Commission on International Trade Law Arbitration Rules 1976, art 35 [UNCITRAL Rules].

45 Alexis Mourre "Arbitrability of Antitrust Law from the European and US perspectives" in Gordon Blanke and Phillip Landolt (eds) EU and US Antitrust Arbitration: A Handbook for Practitioners (Kluwer Law International, The Hague, 2011) 3 at 11:

There is nowadays a general consensus that arbitrators have the powers to apply mandatory rules, either principally or incidentally, and to draw the civil consequences of a violation of said rules, under the control of the judge who will be called upon to assess the award's validity and/or enforceability. 
matters of bribery, this translates into the following dilemma: which rules should be relevant and/or applicable to the issue of bribery if it is invoked in arbitration proceedings? As has been shown above, this dilemma is not moot, as the notion of bribery and the range of prohibited actions differs across jurisdictions.

The starting point is, of course, the choice of law made by the parties. ${ }^{46}$ However, the parties cannot expect to choose a law that is lenient on some forms of bribery or purchase of influence and expect the tribunal to honour that choice in each and every case. ${ }^{47}$ So, which rules matter?

First, irrespective of the law chosen by the parties, the tribunal might observe the mandatory rules of the country where the contract is to be performed. However, not every mandatory rule will be given equal treatment. ${ }^{48}$ Normally rules will be accorded a greater impact if they indeed try to protect a goal that looks legitimate and recognisable, although it need not be shared by other jurisdictions. Thus, a blanket prohibition of intermediaries contained in lex loci solutionis is unlikely to be enforced ${ }^{49}$ and will not have the same weight as, for instance, prohibition of private bribery, or purchase of influence. Applying sweeping prohibitions from the place of performance runs a risk of the award being set aside for being contrary to a much more permissive standard existing in an overwhelming number of jurisdictions. In other words, transnational attitudes towards agents and intermediaries (allowed as a matter of principle) would trump local or parochial prohibitions. ${ }^{50}$

The second potential source of the overriding norms outside the proper law itself is the law of the seat. The "pressure" of the public policy and mandatory norms of the lex arbitri is something arbitrators are always fully aware of, since the courts of the place of the seat might be called on later to set the award aside. Yet the public policy and mandatory rules of the seat will not be automatically applied in each and every case. In order to qualify, there has to be a sufficient nexus between lex arbitri and the case; that is, the case has to touch upon local public interest in a manifest

46 See for example Swiss Federal Code on Private International Law, above n 42, at art 187; Belgian Judicial Code, above n 44, at art 1700; Arbitration Act 1996 (UK), above n 44, at s 46; ICC Rules of Arbitration, above n 44, at art 21(1); AAA Arbitration Rules, above n 44, at art 28(1); DIS Rules, above n 44, at art 23(1); UNCITRAL Rules, above n 44, at art 35(1).

47 As it for instance did in an AAA arbitration decided between Northorp and Triad, where the tribunal chose to disregard a Saudi decree that prohibited payment of commissions to intermediaries. The award was eventually enforced: Northorp Corporation v Triad International Marketing 811 F 2d 1265 (9th Cir 1987). Similarly, the tribunal in Consultant (State Y) v State Agency (State Z) and State Owned Bank (State Z) (Final Award) (1994) 21 YBCA 79, found that it is only bound to apply mandatory rules of lex contractus.

48 Naturally, a precondition is that the rule is truly mandatory. For instance a circular of the Kuwaiti Ministry of Defence was found not to possess such quality: F, $U v$ W Inc (Final Judgment) [1995] ASA Bulletin 225.

49 X Ltd (Great Britain) v YSA (France) (Award) [1988] ASA Bulletin 136; "Extracts from an ad hoc Award rendered in 1989 in Geneva" [1991] ASA Bulletin 239.

50 Decision of the Swiss Supreme Court Hilmarton Ltd (UK) v Omnium de Traitementet de Valorisation OTV (France) (1994) 20 YBCA 663. 
and profound way. ${ }^{51}$ Further, in arbitral matters the concept of public policy of the seat is further constrained to "international public policy", in order to emphasise the sacrosanct nature of the rules that comprise it. ${ }^{52}$ Here, the "internationality" of public policy denotes its operation even in cases with a foreign element, and not its origin - its source and object of protection is still a national legal system. For instance, an English court labelled English policy against contracts of purchase of influence as "purely domestic", although the country of performance shared the same attitude towards such transactions. ${ }^{53}$

There is one more potential source of legal rules before the arbitral tribunal that might interfere with the methodology of choosing applicable norms as described above. Namely, not being part of any judiciary, arbitration tribunals may resort to rules that have not been enacted by any given State. Arbitrators can in such cases rely on "transnational public policy". ${ }^{54}$ Unlike "international public policy", which is national in origin but international in its content, transnational public policy represents fundamental legal principles upon which there is a broad consensus in the international community. ${ }^{55}$ Transnational public policy may be used as a bar to enforcement of the contract, or as a tool to circumvent the application of an otherwise applicable law. When it comes to bribery, the convenience of this tool in international commercial arbitration is limited. As shown above, transnational public policy exists where there is a "broad consensus". Yet how is breadth measured by the number of States, or by their relative economic and political importance? Is one allowed to distil a transnational policy from the collective attitudes of some more exclusive club (like the

51 Compare Rome I, above n 42, at arts 9(2) and 21.

52 As noted in Howard M Holtzmann "Commentary" in International Chamber of Commerce 60 Years of ICC Arbitration: A Look at the Future (ICC Publishing, Paris, 1984) 361 at 364:

International public policy, according to a generally accepted doctrine, is confined to violation of really fundamental conceptions of legal order in the country concerned.

Or, as put by Pierre Mayer "Effect of International Public Policy in International Arbitration?" in Loukas A Mistelis and Julian DM Lew (eds) Pervasive Problems in International Arbitration (Kluwer Law International, The Hague, 2006) 61 at 61, international public policy has two meanings: the concept of public policy as applied in international private law (as an obstacle to the application of foreign law or recognition of foreign judgments), or a part of the public policy that belongs to international law (UN embargoes and the like).

53 In the end, the agreement was unenforceable because it was contrary to the public policy of the loci solutionis. English prohibition alone would have been insufficient. See Lemenda Trading Co Ltd v African Middle East Petroleum Co Ltd [1988] 1 QB 448 at 459.

54 Pierre Lalive "Transnational (or Truly International) Public Policy and International Arbitration" in Pieter Sanders (ed) ICCA Congress Series No 3 (Kluwer Law International, The Hague, 1986) 257.

55 See in that sense Resolution of the Institut de Droit International Equality of Treatment of the Law of the Forum and of Foreign Law Session of Santiago de Compostela (12 September 1989), art II(d), which reads: "It is recommended that the applicable foreign law shall only be set aside if its effects are manifestly contrary to public policy". 
OECD)? States have different definitions of bribery and do not incriminate the same range of behaviour.

There are two possible ways to approach the question of transnational public policy when it comes to bribery. One way is to find strength in numbers, which would mean that when support for incrimination of certain behaviour is overwhelming, such prohibition should be treated as one of transnational public policy. Prohibition of the bribery of public officials (prohibited in over 160 countries) qualifies as such. However, when it comes to prohibition of private bribery, the numbers are not so conclusive: currently more than 90 countries in the world prohibit it, and it is incriminated in about two-thirds of the OECD jurisdictions (22 out of 34 countries). ${ }^{56}$ There would be even less support for finding that prohibitions of facilitation payments and purchases of influence amount to policy of transnational quality. The other approach in identifying transnational policy would be to look into the trends. This would take into account that the number of jurisdictions where private bribery is incriminated is growing ${ }^{57}$ and would inevitably amount to the equivalent of an "activist judge". Without doubt, this is where the arbitrators' subjective views will come into play. ${ }^{58}$ In any event, if the arbitrator is advised to use the "nuclear" option of "international public policy" only in extreme situations, such advice is even more appropriate when it comes to the invocation of "transnational public policy".

56 As far as OECD countries are concerned, private bribery is incriminated in: Bundesgesetz Gegen den Unlauteren Wettbewerb (Austria), above n 10, at §10; Code pénal (Belgium), above n 10, at art 504bis, §1, [1] and [2]; Criminal Code (Canada), above n 10, at s 121; Criminal Code (Czech Republic), above n 10, at s 128b; Straffeloven (Denmark), above n 10, at s 299; Penal Code (Finland), above n 10, at ch 30, s 7; Strafgesetzbuch (Germany), above n 10, at s 299; Criminal Law Convention on Corruption (Greece), above n 10, at arts 7 and 8; a Büntető Törvénykönyvröl (Hungary), above n 10, at s 253; Penal Law (Israel), above n 10, at s 291; Il Codice Civile Italiano (Italy), above n 10, at s 2635; Loi du 23 mai 2005 (Luxembourg), above n 10, at s 3; Wetboek van Strafrecht (the Netherlands), above n 10, at art 328ter, read jointly with Penal Code (the Netherlands), above n 10, at art 51; Secret Commissions Act 1910 (New Zealand), above $n$ 10, at ss 3, 4 and 8; Lovom den almindelige borgerlige Straffelovs Ikrafttræden (Norway), above n 10, at ch 26, s 275; and Savings Bank Act (Norway), above n 10, at s 20; Kodeks karny (Poland), above n 10, at art 296a; DL 28-84 com alterações regime em vigor em matéria de infracções antieconómicas e contra a saúde pública (Portugal), above n 10, at arts 41-B.1 and 41-C.1; Trestný Zákon (Slovakia), above n 10, at ss 160 and 161; Criminal Code 2007 (Slovenia), arts 245-248; Brottsbalken (Sweden), above n 10, at s 2, ch 20; Code pénal (Switzerland), above n 10, at art 158; Bribery Act 2010 (UK), above n 10, at ss 1-3.

57 Pursuant to the data submitted by the national authorities of the UNCAC member states, bribery in the private sector is currently incriminated in more than 90 jurisdictions worldwide - see data provided in relation to UNCAC, above n 1, at art 21, available at United Nations Office on Drugs and Crime portal "Legal Library", above n 10.

58 Mayer in Mistelis and Lew, above n 52, at 69. 


\section{THE IMPACT OF THE FINDING OF BRIBERY ON THE FATE OF CONTRACTS}

As laid out in Part III above, typical scenarios in which bribery allegations are invoked in the context of international commercial arbitration are those involving intermediaries acting as a vehicle for funnelling bribes. On the basis of such bribes, the principal obtains some favour and, more often than not, obtains a contract from the target of the bribe (be it a company or a State). The arbitrator then usually faces the claim of the intermediary (for its "commission"), or the target of the bribe (for rescission, or adaptation of the contract procured by bribery). One can, of course, encounter alternative scenarios; for example, a "renegade" or simply overzealous agent who bribes the target not on the instruction (explicit or implicit) of the principal, but in order to make sure he or she gets his or her commission. In any event, if the arbitrators find that bribery indeed took place, they have to determine the civil law consequences of such a finding, in particular the fate of the underlying or resulting contracts.

When it comes to the contracts directed at bribery (that is, those between the principal and the intermediary who serves as a go-between), the contracts' fate is not controversial. Although national laws differ on what is perceived as bribery, their treatment of what they actually label as bribery is uniform - contracts aimed at bribery are illegal and are therefore null and void. This civil law consequence is not only contained in the provisions of national laws ${ }^{59}$ and international conventions, ${ }^{60}$ but is also identified as a principle of transnational public policy. ${ }^{61}$ Therefore, no matter which set of rules a tribunal has resorted to (national or transnational) when examining the potential bribery, once it finds that, under the applicable rules, bribery indeed took place, the contract aimed at bribery will be held null and void. It should be noted that sometimes this consequence will follow even if the applicable law (that is, the chosen law or the law of the seat)

59 See for example Schweizerisches Obligationenrecht (Switzerland), art 20 (translation: Swiss Law on Obligations); Bürgerliches Gesetzbuch (Germany), §134 (translation: Civil Code); Law on Obligations (Serbia), arts 47 and 103; Civil Code of the Russian Federation (Russian Federation), art 169 in relation to art 167.

60 Council of Europe Civil Law Convention on Corruption 174 ETS (opened for signature 4 November 1999, entered into force 1 November 2003), art 8(1) reads "[e]ach party shall provide in its internal law for any contract or clause of a contract providing for corruption to be null and void."

61 See for example Centre of Transnational Law "No.IV.7.2(a) - Invalidity of contract due to bribery" TRANS-LEX.org <www.trans-lex.org>:

Contracts based on or involving the payment or transfer of bribes ("corruption money", "secret commissions", "pots-de-vin", "kickbacks") are void (emphasis added).

See also Olaf Meyer "The Formation of a Transnational Ordre Public against Corruption - Lessons for Arbitral Tribunals" (Paper presented at Global Challenges of International Sales Law Conference, University of Florida, Florida, 11-12 November 2011). 
does not treat a particular conduct as bribery, since the sanction of nullity can follow from a contract the object of which is immoral, and consequently illegal. ${ }^{62}$

Normally, a null and void contract gives rise to obligations for the actors to make restitution for what they have received pursuant to the void contract. However, when it comes to bribery, these obligations are curtailed by the principle nemo auditor turpitudinem suam allegans, which means that no restitution will be due. ${ }^{63}$ In some national laws, the courts are allowed to order parties in such cases to hand over what they have received in such a manner to the State or to a municipality, ${ }^{64}$ or to allow partial restitution. The exercise of the former option does not appear to be at the disposal of an arbitral tribunal, as it introduces a penal element to civil proceedings.

Unless the tribunal is empowered by law to order the partial restitution, the end result might be that one of the two parties (both of them unconscionable) walks away with a pot of gold or receives a windfall, a consequence of the application of the in pari delicto potior est conditio possidentis maxim. ${ }^{65}$ For instance, the intermediary will keep the advance for the bribe it has not used, or the principal would get what it wanted (the target contract or the favour) without reimbursing the intermediary for its "services", including the expenses for the bribe. This "no-honesty-no-equity" outcome would appear to favour the most dishonest party, ${ }^{66}$ the one who has outmaneuvered its counterpart. ${ }^{67}$ Some tribunals have expressed their unease when deciding to stick to the strict principle of no restitution. ${ }^{68}$ However, this threat of betrayal and the inequitable ending of affairs is a potent tool in the fight against corruption. ${ }^{69}$ Mutual trust is the main ingredient of the illegal scheme. For instance, cartels are highly dependent on mutual cooperation and trust, but there are, at the same time, powerful incentives for the members of the cartel to break their promises and freeride at the expense of others. This is why cartels are inherently unstable and this instability deters

62 See for example Schweizerisches Obligationenrecht (Switzerland), above n 59, at art 20; Law on Obligations (Serbia), above n 59, at art 49; also BGH NJW 1986 at 2406. See also Broker v Contractor, above n 17, which was, nonetheless, set aside in the Swiss courts: Cour de Justice (Court of Appeal), Geneva in 1984, and the Tribunal Fédéral (Supreme Court), Geneva in 1990; Omnium de Traitementet de Valorisation - OTV (France) v Hilmarton (UK) (1994) 19 YBCA 214.

63 See for example Bürgerliches Gesetzbuch (Germany), above n 59, at $\$ 817$.

64 See for example Law on Obligations (Serbia), above n 59, at art 104(2); Civil Code of the Republic of Poland, art 412.

65 In equal fault, better is the condition of the possessor.

66 For a critique, see Mirko Möller "Leistungskondiktion trotz beiderseitiger Sittenwidrigkeit? - Die Einschränkung des" §817 S 2 BGB durch den BGH NJW 2006 at 268.

67 Meyer, above n 61, at 10.

68 Case 3913 [1981] Coll Vol 497; Company $S$ v Company F, above n 17.

69 Johann Graf Lambsdorff "Making corrupt deals: contracting in the shadow of the law" (2002) 48 Journal of Economic Behavior \& Organization 221. 
potential participants. Similarly, the possibility of getting nothing and picking up the bill for the other party serves as a potential deterrent for those who plan to engage in bribery.

The other contract that might actually be at stake before the tribunal is the one allegedly procured by bribery. Namely, the subject-matter of the arbitration might be the contract not between the principal and the intermediary, but between the successful principal and the target of that principal's bribery operation. The target company might allege that the contract concluded between the parties has been procured because its officers were bribed and it is thus tainted. But what follows from such "taintedness", if the applicable law indeed labels the disputed conduct as "bribery"? The answer depends on whether one views the existence of the procured contract as primarily the infringement of the public interest, or the interest of the private actors.

One option would be to apply the same yardstick, and to treat contracts procured by bribery just like the contracts aimed at bribery - null and void ex lege. A possible justification for this position would be that the anti-corruption policy does not serve to protect the parties to the dispute, but rather the citizens and consumers who will eventually foot the corruption bill through paying higher prices and taxes. It appears that this zero-tolerance approach is regarded by some as a transnational principle. ${ }^{70}$ However, there is "no transnational consensus" that ipso iure and ab initio invalidity of the contracts procured by bribery represents a shared transnational legal and moral value. ${ }^{71}$

This solution (null and void ex lege) would be far from adequate and would sacrifice the legitimate interests of innocent parties at the altar of the abstract notion of public interest. That is why contracts procured by bribery are usually treated as voidable: because of the lack of valid consent, for example, through deceit or excess of authority. ${ }^{72}$ Proving requirements under any of the two may vary considerably from one national law to another. ${ }^{73}$ In practice, the fallout of such avoidance will sometimes be very difficult to carry out, especially in complex and long-term

70 See for example Centre of Transnational Law, above n 61:

Contracts based on or involving the payment or transfer of bribes ("corruption money", "secret commissions", "pots-de-vin", "kickbacks") are void (emphasis added).

71 See Raeschke-Kessler and Gottwald in Muchlinski, Ortino and Schreuer, above n 3, at 595.

72 Council of Europe Civil Law Convention on Corruption, above n 60, at art 8(2), reads:

Each Party shall provide in its internal law for the possibility for all parties to a contract whose consent has been undermined by an act of corruption to be able to apply to the court for the contract to be declared void, notwithstanding their right to claim for damages.

See also International Institute for the Unification of Private Law UNIDROIT Principles of International Commercial Contracts 2010 (Rome, 2010) at art 3.1.1, Illustration 16. Sometimes, this possibility is provided for interested third parties. See Meyer, above n 61, at 12 for further references; Raeschke-Kessler and Gottwald in Muchlinski, Ortino and Schreuer, above n 3, at 595.

73 Compare national reports in Olaf Meyer (ed) The Civil Law Consequences of Corruption (Nomos, BadenBaden, 2009): Olaf Meyer, at 156 (Germany); C Takoff, at 203 (Bulgaria); D Kraft, at 209 (England). 
contracts that have been partially performed. Where the restitutio in naturam is impossible, the briber should be compensated only for his or her expenses, and not for the full market value of his or her performance. Awarding a briber full market value would allow them to actually profit from their corrupt dealings. ${ }^{74}$

Finally, it might be observed that, faced with different choice-of-law approaches with respect to the issue of bribery, the tribunal might be tempted to eventually use the one that will tap into the body of rules (national or perceived transnational) that bring it to the desired solution on the merits. Taking the "transnational route" might be tempting, but is increasingly difficult to defend or justify the further one gets from simply observing the illegality of public bribery. Application of national laws - be it pursuant to the traditional conflict analysis, voie directe, or other method - remains a more reliable solution.

\section{JUDICIAL SCRUTINY OF THE RESULTING AWARDS}

Allegations of corrupt practice, bribery especially, will not easily succeed before an arbitral tribunal. They might fail at the level of choice-of-law (applicable law does not incriminate a particular type of agreement or conduct) or might simply fail to be proven (since the burden of proof of criminal matters in arbitration is often set rather high). ${ }^{75}$ If the defence succeeds and the claim (for example, an intermediary's claim for "commission") is rejected, unsuccessful claimants' chances for reversing the decision in most jurisdictions will be close to zero. Even if the tribunal has erred on the side of caution and saw bribery where there was none, the Model Law ${ }^{76}$ (and its progeny) and the New York Convention ${ }^{77}$ offer no foothold for review of the merits, except when it comes to breaches of public policy.

If the defence fails, the only chance for the unsuccessful party would lie in invoking public policy grounds for setting aside the award ${ }^{78}$ or refusing its recognition and enforcement. ${ }^{79}$ Since this is the ground to be examined ex officio, invoking it is, strictly speaking, not necessary, but will

74 See Cameroon Airlines v Transnet Ltd [2004] EWHC 1829 (CA).

75 Alternatives do exist, such as reversal of the burden of proof. For the most recent and comprehensive overview of the matter, see Wilske and Fox in Kröll and others, above n 20, at 489-505. See also Hwang and Lim, above n 2, at 14-25.

76 Model Law, above n 26.

77 New York Convention, above n 25.

78 See for example Model Law, above n 26, at art 34(2)(b)(i); Swiss Federal Code on Private International Law, above n 42, at art 190(1)(e); French Decree No 2011-48 of 13 January 2011, reforming the law governing arbitration, art 1492(5); German Act on the Reform of the Law relating to Arbitral Proceedings 1998, s 1059

79 See for example New York Convention, above n 25, at art 5(2)(b); Arbitration Act 1996 (UK), above n 44, at s 81(c); French Decree No 2011-48, ibid, at art 1488. 
normally be done together with the presentation of the relevant facts. The weakness of the public policy defence and the general distaste for its application in the field of international commercial arbitration is well documented ${ }^{80}$ However, prohibition of bribery certainly falls within the domain of public policy. Courts deciding on the setting aside will examine the award in light of the international public policy of the forum. ${ }^{81}$ Courts approached for recognition will examine whether the enforcement of such an award will run contrary to the international public policy of the country of recognition. ${ }^{82}$ Therefore, although it is relatively easy to accept the proposition that public bribery is contrary to every domestic, international and transnational public policy, and that enforcement of the award that puts a stamp of approval on such a transaction is contrary to public policy, ${ }^{83}$ other types of conduct may fail to clear the threshold of public policy in some jurisdictions. In other words, in matters other than bribery of the public official, successful use of the public policy ground will depend on the severity and comprehensiveness of the local legislation. The impact and reach of the public policy ground for annulment or refusal of recognition will vary accordingly.

Invoking public policy imports other dilemmas. Although courts will normally not examine the merits of the award, public policy considerations may alter this attitude. Public policy issues are

80 As summarised in Judge Borrough's famous remark, public policy is "never argued at all but when other points fail": Richardson v Mellish (1824) 2 Bing 229 at 252, 130 ER 294 (Comm Pleas) at 303. See for example Marie Louise Seelig "The Notion of Transnational Public Policy and its Impact on Jurisdiction, Arbitrability and Admissibility" (2009) 57 Annals of the University of Belgrade Faculty of Law 116; Lalive, above n 54, at 258 et seq; RH Kreindler "Approaches to the Application of Transnational Public Policy by Arbitrators" (2003) 4 Journal of World Investment 239; and Audley Sheppard "Public Policy and the Enforcement of Arbitral Awards: Should there be a Global Standard?" (2004) 1 Transnational Dispute Management 5.

81 Jean Francois Poudret and Sébastien Besson Comparative Law of International Arbitration (Sweet \& Maxwell, London, 2007) at 763-765; James D Fry "Désordre Public International under the New York Convention: Wither Truly International Public Policy" (2009) 8 Chinese JIL 81 at 86 et seq; Algerian Code of Civil Procedure, art 458 bis 17, as amended; Lebanese Code of Civil Procedure, arts 814 and 817(5); Law No 1879/02 on Arbitration and Mediation 2002 (Paraguay), art 46(b); and Legislative Decree No 1071 Regulating Arbitration (Peru), art 63(1)(f).

82 BGH, IPRax 2000 at 580; Slovenian Manufacturer v German Exclusive Distributor (1999) 29 YBCA 687 at 686 and 696; OLG Schleswig, RIW 2000, 30 March 2000 at 705; OLG Bremen, BB 2000, 30 September 1999, Appendix 12 at 18; decision of the Cour d'Appel de Beyrouth of 21 February 2008 [2009] J Arab Arbitration 310 at 314 .

83 The International Law Association Committee on International Commercial Arbitration's Interim Report on Public Policy as a Bar to Enforcement of International Arbitral Awards (2000) at 22, states that "it is arguable that there is an international consensus that corruption and bribery are contrary to international public policy". On some occasions, however, the courts were careful to assign a lover level in the "scale of opprobrium" than, for example, drug trafficking, eventually leaving the award intact: see Westacre Investments Inc v Jugoimport-SPDR Holding Co Ltd [1998] 3 WLR 770 (QB) at 798-800. There was a similar result in $R v V$ [2008] EWHC 1531 (QB). 
woven into the award. Deciding on whether the tribunal has actually endorsed bribery might require examination of how the award was made and what its "ingredients" were. How intrusive may this review turn out to be? The answer is not uniform.

In the face of corruption allegations, some courts have continued to value finality of the award and have deferred (to a great extent) to legal and factual findings made by tribunals. For instance, one court held that erroneous application of the criminal law standard would not be examined, ${ }^{84}$ while the other maintained that it would not re-examine a tribunal's decision not to apply prohibition of intermediaries of loci solutionis. ${ }^{85}$ Other courts have employed a completely different approach, opening a de novo review of factual and legal findings (wrong assessment of evidence, nonapplication or erroneous application of law, and so on). ${ }^{86}$ Some courts tried to identify the trigger that would justify abandonment of deference and application of a higher standard of review: ranging from a circular argument that there should first be a "blatant, actual and concrete" breach of international public policy, ${ }^{87}$ to a multi-stage test, whereby further inquiry is conditional upon finding that there is "prima facie evidence" from one side that the award is based on an illegal contract, and that further examination is justified. ${ }^{88}$ The latter approach has been endorsed by authors such as Michael Hwang and Kevin Lim, who argue that the initial, prima facie, filter should also encompass assessment of the nature of the alleged illegality. ${ }^{89}$ It is fair to conclude that the approach of the courts on this matter will continue to be anything but uniform. Complete deference seems to be an ill-suited protector of public policy principles, and it is understandable why courts and arbitrators attempt to devise a test ("trigger") for further inquiry. It is also notable that the approach of complete deference to the findings of the arbitrators requires parties to furnish fresh, new evidence of illegality. This will be available only in the rarest of circumstances.

Although the bribery defence "card" will most likely be played as early as possible, it is conceivable that it could be used for the first time in the annulment/recognition proceedings for tactical reasons. Normally, the parties to the arbitration can later invoke a defect only if they have objected to it in a timely manner. However, it could be argued that this principle should not be automatically applicable in the context of deficiencies that are examined ex officio. In other words, if the award is challenged for effectively upholding bribery, the facts upon which the challenge is

84 Judgment of the Swiss Federal Tribunal of 28 January 1997 (1998) 16 ASA Bulletin 118.

85 Northorp Corporation v Triad Financial Establishment 593 F Supp 928 (CD Cal 1984).

86 See for example European Gas Turbines SA (France) v Westman International Ltd (UK) (1993) 20 YBCA 198.

87 See for example Moreau v Verhoef (Final Decision) (2001) 4 Rev Arb 805.

88 See Soleimany v Soleimany [1998] 3 WLR 811.

89 Hwang and Lim, above n 2, at 14-25. 
based need not be fresh or new to the party invoking them, nor would it be required that they have already been examined by the tribunal..$^{90}$

\section{CONCLUDING REMARKS}

While it is tempting to automatically label the fight against "corruption and bribery" as a matter of public policy, a more detailed examination reveals that there are still considerable differences between jurisdictions when it comes to how "bribery" is defined. There is a strong consensus only when it comes to the core of that notion (the bribery of public officials).

In any event, legislation against bribery reopens - in the context of international commercial arbitration - a relatively familiar set of issues relating to the application of overriding mandatory provisions and the ambit and operation of the various shades of "ordre public". What differs from the standard fare of mandatory rules is, however, the intensity of potential infringement of considerations of public policy. Potentially strong public policy concerns influence not only the methodology of determining applicable rules (where departure from party autonomy will often be necessary), but also touch upon the role of the arbitrators and their relationship vis-à-vis judicial machinery. Any specific legislative duty to report illegality will trump an implied (and express) duty of confidentiality, provided that its scope of application (personal and territorial) reaches the arbitrators. Moral imperative alone is unlikely to have the same effect on an arbitrator's decision to report or not report.

Public policy considerations also influence substantive reactions towards the finding of illegality. Some of these considerations appear lopsided (for example, the no restitution rule), but they nevertheless serve a wider policy goal which might not be apparent in the context of a single case. Nuances of civil law consequences across jurisdictions also invoke caution against the overzealous invocation of transnational ordre public when it comes to findings of illegality, since it is difficult to identify "transnational" principles that would logically be applied to compliment the initial finding and determine the civil law consequences of a finding of bribery.

Finally, the courts stand as the final guardians of public policy, including the public policy against bribery and corruption in general. While arbitral tribunals can draw on a wider choice of potentially applicable rules (overriding mandatory rules in particular), national courts cannot go further than protecting the limited turf of the international public policy of that forum. In doing so, the courts have to solve the difficult issue of balancing the cardinal principle of the finality of arbitral awards with the imperative of safeguarding public policy. Not surprisingly, no ready

90 A similar distinction is also made in the Swiss Federal Tribunal Law, art 123, albeit in a different context of revision of the award: crime and felony warrant revision irrespective of the novelty and freshness of the facts. For a similar line of argumentation, see the dissenting opinion of Waller LJ in Westacre Investments Inc v Jugoimport-SDRP Holding Co Ltd [1999] 3 WLR 811 (CA) at 833 et seq. 
formula for achieving this balance has emerged until now, but it appears that outright deference to the findings of the tribunal is particularly unsuitable. 